Article

\title{
Socio-Ecological Perceptions of Wildfire Management and Effects in Greece
}

\author{
Palaiologos Palaiologou ${ }^{1, * \mathbb{D}}$, Kostas Kalabokidis ${ }^{1}$, Andreas Troumbis ${ }^{2}$, Michelle A. Day ${ }^{3}$ (D), \\ Max Nielsen-Pincus ${ }^{4}\left(\mathbb{D}\right.$ and Alan A. Ager ${ }^{3}$ \\ 1 Department of Geography, University of the Aegean, Mytilene, 81100 Lesvos Island, Greece; \\ kalabokidis@aegean.gr \\ 2 Department of Environment, University of the Aegean, Mytilene, 81100 Lesvos Island, Greece; \\ atro@aegean.gr \\ 3 USDA Forest Service, Rocky Mountain Research Station, Missoula Fire Sciences Laboratory, \\ Missoula, MT 59808, USA; michelle.day@usda.gov (M.A.D.); alan.ager@usda.gov (A.A.A.) \\ 4 Department of Environmental Sciences and Management, Portland State University, \\ Portland, OR 97201, USA; maxnp@pdx.edu \\ * Correspondence: palaiologou.p@aegean.gr; Tel.: +30-22510-36435
}

Citation: Palaiologou, P.;

Kalabokidis, K.; Troumbis, A.; Day, M.A.; Nielsen-Pincus, M.; Ager, A.A. Socio-Ecological Perceptions of Wildfire Management and Effects in Greece. Fire 2021, 4, 18. https:// doi.org/10.3390/fire4020018

Academic Editor: Fantina Tedim

Received: 11 March 2021

Accepted: 30 March 2021

Published: 2 April 2021

Publisher's Note: MDPI stays neutral with regard to jurisdictional claims in published maps and institutional affiliations.

Copyright: (c) 2021 by the authors. Licensee MDPI, Basel, Switzerland. This article is an open access article distributed under the terms and conditions of the Creative Commons Attribution (CC BY) license (https:// creativecommons.org/licenses/by/ $4.0 /)$.

\begin{abstract}
Adapting to the growing frequency of catastrophic wildfires in Greece and mitigating their effects is a complex socio-ecological problem. We used an online survey to query more than 100 engaged stakeholders who can potentially influence possible legislation and fire management organizational reform, emphasizing civil protection agencies and research entities. We focused the questionnaire on the importance of different wildfire effects to understand which were considered negative or unacceptable, indifferent, or positive. For fire prevention, we examined the range of acceptance and views on fuel management and fire use activities that are limited in extent or not allowed in Greece. We also examined the beliefs regarding ignition causes and responsibility, in addition to how different policies might reduce wildfire-related problems. The results revealed an emphasis on reforming wildfire management policies to deal with the way society and agencies function and interact, and mitigate the influence of climate change in wildfire frequency and behavior. In addition, respondents had a negative stance towards allowing wildfires to burn for resource objectives and a strong belief that arsonists are behind most ignitions. They also believe the lack of a national cadaster system is a major source of wildfire-related problems. The results indicate little support for fuel treatments, but increased acceptance for the legalization of fire use during firefighting (backfires). This study summarizes current wildfire perceptions in Greece and identifies opportunities and barriers to changes in wildfire governance to improve risk management programs and guide post-fire management and mitigation.
\end{abstract}

Keywords: fire risk governance; society; fuel management; social survey; controlled burn

\section{Introduction}

Catastrophic wildfires over the past few decades in Greece suggest that existing risk governance policies are inadequate to address future fire hazards and effects. Despite the rapid advancement of scientific knowledge regarding wildfire risk and mitigation practices, little has been done to improve existing wildfire management policies [1]. The most significant fire suppression and forest management regulations were established almost four decades ago (Law 998/1979) and strongly favor fire suppression (about USD 400 million annually invested), with only minor funding for fire prevention and fuel management programs (about USD 25 million annually) [1-3]. The current fuels reduction budget provides the Greek Forest Service (GFS) with direct funding adequate to treat a small area (20,000 ha) spread across the entire country per decade (approximately 2000 ha annually). This amounts to about $1 \%$ of the forested landscape (about 2.8 million ha), where 
over 42,000 ha burn each year from 1400 fires on average [4,5]. The minimal investment in fuel treatments [6] ensures that managing future wildfire risk will rely solely on fire suppression efforts to achieve active fire containment, even for low-intensity fires, until policies change.

In addition, barriers to wildfire management exist on non-public lands. One of the main obstacles for private forests is their small size and the owners' reluctance to invest in wildfire management due to reduced prospects for profit, in addition to the conflicts caused by joint ownerships and legal restrictions that paralyze management decisions [7]. Fuel reduction and timber production are regulated by the GFS on both state lands (65\% of all forests) and large privately-owned forested lands, but with limited application to smaller private lands and forests without management plans. In addition, current laws do not allow the deliberate use of landscape burns, including prescribed fire or backfires during fire suppression operations. By contrast, prior to large-scale, postwar-era land abandonment [8,9], fire was widely employed by local populations to clear forests of excessive vegetation and noxious weeds, the absence of which has caused forest encroachment into formerly agricultural lands $[10,11]$. The wildfire problem in Greece has been exacerbated by changing demographic trends and the economic environment, which have transformed the Greek landscape [12-14]. More specifically, land ownership is highly fragmented [15], the wildland-urban interface (WUI) is rapidly expanding, and land abandonment is widespread [16-18].

Given the multiple and complex challenges to wildfire governance in Greece, reshaping fire policies will first require an in-depth understanding of societal attitudes and beliefs towards wildfire-related issues [19-22]. For instance, questions may include the following: What are the current views on fire use for fuel management? What increases wildfire suppression complexity and costs? What are the causes of increased fire frequency and intensity? Which wildfire management approaches can better control fire activity most cost-effectively? What are the most important fire effects?

To address these and other related questions on the social aspects of fire, we conducted a web-based survey of professionals in wildfire management and research, and stakeholders interested in wildfire policy. A major objective of our study was to understand the prevalent trends and perspectives of engaged stakeholders on a series of issues related to wildfire prevention and management. These respondents hold positions in state and government agencies that offer the potential to influence fire risk governance and policies, and we expected that their answers would be informed by their job experience and expertise. We were also interested in exploring stakeholders' views on post-fire effects on the landscape, aesthetics, vegetation, fauna, infrastructure, and the economy, and what factors influence their decision on characterizing a fire as important in terms of induced effects on society and nature. Several questions focused specifically on prescribed fire use for fuel management and suppression backfires, while others on evaluating the current policies and the role of state agencies.

Based on Greek laws and our previous knowledge, we hypothesized that (i) the use of prescribed fire lacks even minimal support in Greek society, as reflected in our sample responses, and (ii) despite the lack of effectiveness, stakeholders perceive wildfire suppression policies more favorably compared to preventive fire management. Finally, we identified topics and issues with large differences on what is considered to be important between those respondents identified as experts vs. non-experts. Our results provide insights on the social barriers for improving wildfire risk governance in Greece and can help public officials promoting legislation to reform current wildfire management policies.

\section{Materials and Methods}

\subsection{The Greek Landscape}

Greece covers an area of $132,000 \mathrm{~km}^{2}$ on the southern tip of the Balkan peninsula. More than 10,000,000 million people reside in 13,500 communities ( 82 people $\left./ \mathrm{km}^{2}\right)$, with more than half residing in three major urban centers (Athens, Thessaloniki, and Patras) 
(Figure 1). A dense road network of 120,000 km connects villages and urban centers, and the landscape is topographically fragmented by numerous mountainous ranges (more than $80 \%$ of the territory), spanning from the northwest to south (more than 40 of its highest peaks are between 2000 to $3000 \mathrm{~m}$ above sea level). Of the thousands of Greek islands, 165 are populated. Numerous cultural heritage monuments and sites dispersed across the Greek landscape are prone to be affected by wildfires (e.g., the Ancient Olympia site burned in August 2007) [23]. In addition to the 200,000 ha of national land in the 10 national forests, 14 national parks were recently established as legal entities (1.1 million ha). More than 200 protected areas of the NATURA 2000 network ( $>4$ million ha) cover more than one-third of the country's total area.

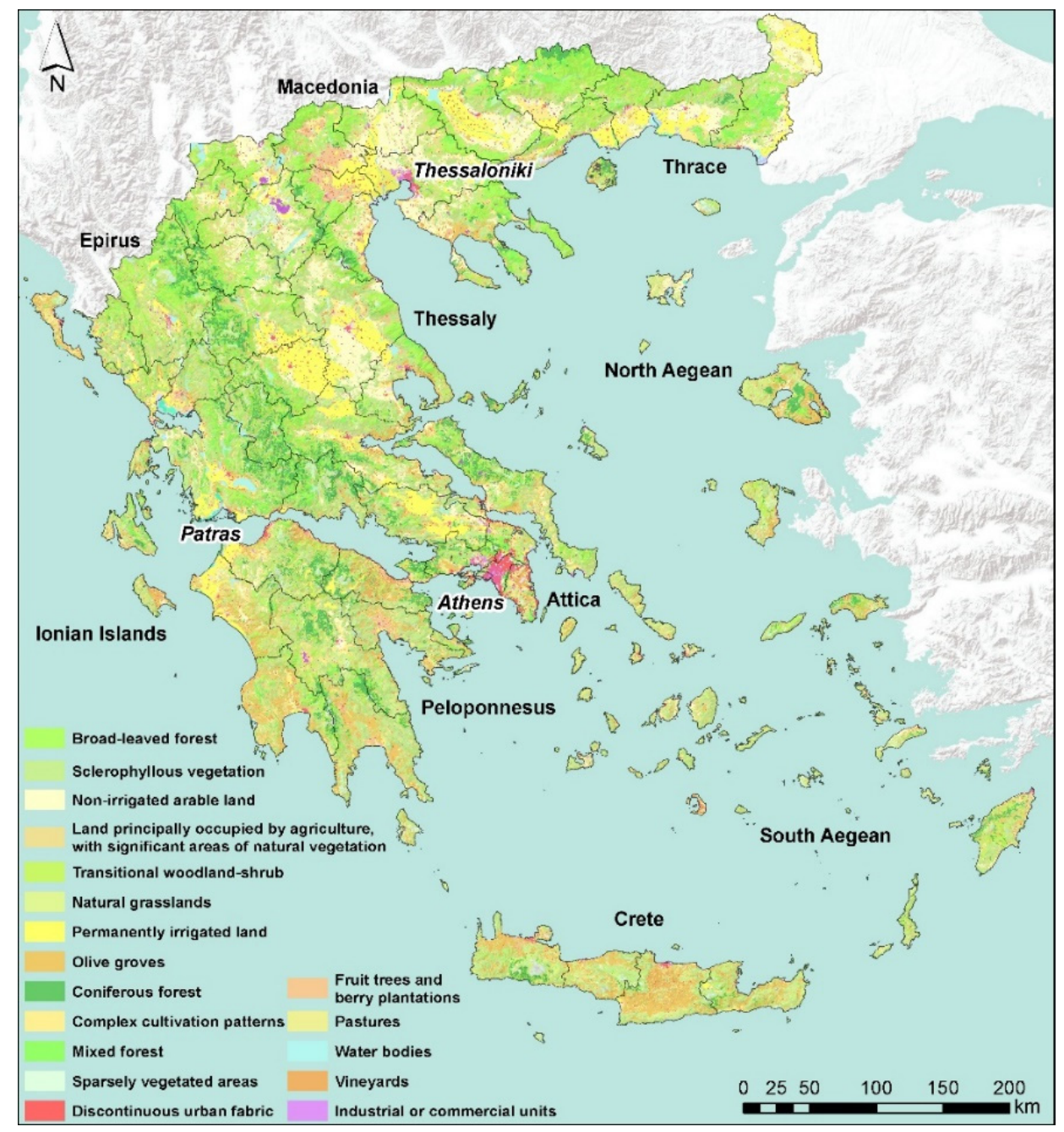

Figure 1. Main regions and urban centers of Greece. Colors describe the dominant land cover types as defined in the Corine 2018 layer [24].

Forest management in fire-frequent, low elevation pine forests and evergreen shrublands is largely avoided, and thus, forests are prone to fuel build-up due to the lack of funding for fuel reduction and the absence of a fire risk management culture. Despite this, management activities are applied by farmers or livestock producers, sometimes unofficially, with traditional land-use practices on agroforestry systems, including resin collection from conifer trees $(89,000$ ha in 1984 vs. 26,000 ha in 2011$)$, grazing on silvopastoral systems by a population of $8,000,000$ sheep and 5,000,000 goats on more than 2,000,000 ha, fuelwood collection, honey production, and forage (e.g., mushrooms, berries, herbs, and seeds). These traditional management practices are threatened by degradation, either through abandonment or intensification - which leads to their conversion to woodlands and crop 
monocultures, respectively [25]—or through repeated wildfires that change landscape characteristics (e.g., the modification of the dominant vegetation types or land uses, erosion, and desertification phenomena), and reduce livestock and agricultural productivity.

The average annual area that has burned over the last 40 years is about 43,000 ha [4], $40 \%$ of which is forested lands. During the period of 1974-2018, 215 wildfires burned between 500 and 2000 ha, 110 wildfires burned between 2000 and 7000 ha, and 35 fires burned more than $7000 \mathrm{ha}$. Only $22 \%$ of the area burned [26] historically occurs in northern Greece ( $48 \%$ of total area) due to high annual precipitation, temperate broadleaf and mixed forests, extended plains, and a better road network than the remainder of the country. In contrast, the southern mainland covers $20 \%$ of Greece but is where $47 \%$ of the area is burned. The Crete, Aegean, and Ionian islands experience a percentage area burned equal to their percentage of the Greek landscape (almost 17\%). Only half of all wildfire events have a verified ignition cause, with most ignitions caused by the burning of agricultural lands and grasslands for clearing unwanted vegetation (33\%), arson $(23 \%)$, negligence $(12 \%)$, lightning $(8 \%)$, and landfill-ignited fires $(6 \%)$. Of all fires, $62 \%$ are ignited from July to September, resulting in $85 \%$ of all area burned.

\subsection{Key Informant Survey}

We conducted a web-based survey of professionals in wildfire management and research and other engaged stakeholders interested in wildfires (i.e., local government officials, non-government organizations, community members, etc.). The survey was conducted during the winter of 2017-2018 (December through February). All respondents were anonymous, but we estimated that approximately 200 people working in the central government, Fire Service, Forest Service, and research organizations received the questionnaire by e-mail, while another 100 individuals were contacted through social networks. We received 106 validly completed responses, representing a 33\% response rate. The questionnaire consisted of 22 questions divided into three groups: (i) general questions about the respondent's status / expertise; (ii) beliefs about general fire prevention and management issues; (iii) rating or ranking of different fire effects (please refer to the Supplementary Material for the transcript and a detailed breakdown of the questionnaire). Respondents were asked to answer the questions based on the situation, conditions, and perceptions relevant to their longest place of residence (place-based knowledge).

The first question group consisted of eight questions regarding their place of residence, gender, age group, employment status and employer, education, and experience with wildfires (Table 1). The second question group consisted of six questions asking for the respondents' beliefs on who is responsible for wildfire ignitions when concurrent fires occur across Greece (as well as in the respondents' home municipalities), attitudes and perceptions about the risk of controlled burns during firefighting and fuel management operations, which policies could potentially reduce wildfire-related problems, what the role of state and society should be towards fuel management, and under what conditions wildfire suppression is considered difficult and complex (Table 1). In the third question group, participants were asked to rate which factors they believed can reduce the forest regeneration potential of burned areas, which post-fire environmental issues they considered the most important, which factors can reduce the aesthetic quality and attractiveness of the affected lands, and how much they could be personally impacted by fatalities and firefighting casualties (Table 1). In addition, we asked for their views on which types of economic losses and infrastructure damage (or destruction) could impact the lives of people living in their municipality.

The questionnaire was constructed with Qualtrics [27], using different question types (Table 1). The respondents were characterized as experts or non-experts. Experts were those respondents that experienced at least three fire incidents during their lives (either as a witness or through their professional career), and with good or excellent working experience on at least two of the following fire-related activities: suppression, fuel management, research and study, post-fire rehabilitation, and the effects of wildfires. 
Table 1. Survey questions, each assigned to one of three groups. The letter in parentheses at the end of the question denotes the question type and the available range of responses referenced in the bottom row.

Personal Questions

General Questions and Beliefs on Fire

Q1.1 In which part of Greece did you reside in the longest? (A)

Q1.2 How many wildfires

have you personally experienced (i.e., either inside or close to the affected area)?

(B)

Q1.3 Please rate your experience with wildfires $(G)$

Q1.4 Employment status (B)

Q1.5 If you are employed, where do you work? (B)

Q1.6 Age class (B)

Q1.7 Highest degree you have received (B)

Q1.8 Gender (B) Prevention/Management

Q2.1 For the prefecture of Greece you selected, who do you think is responsible for most wildfire ignitions? (B)

Rating or Ranking of Different Fire Effects

Q3.1 Based on your experience and knowledge, please rate the effect of the following negative factors on reducing regeneration and vegetation recovery potential after a wildfire, for the prefecture of Greece where you have resided the longest. (E)

Q2.2 When multiple wildfires occur across Greece, who do you think is responsible for most ignitions? (B)

Q2.3 Please rank your understanding and perception regarding wildfire suppression effort complexity (C)

Q2.4 What is your opinion on using controlled fire during firefighting or as prescribed fire to reduce forest fuels? $(\mathrm{H})$

Q2.5 What is your opinion on the specific wildfire-related statements? $(\mathrm{H})$

Q2.6 Which policy do you believe is most capable of reducing the wildfire-related problems? (B)

Q3.2 Based on your experience and knowledge, please rate the importance of the following wildfire effects on the environment, for the prefecture of Greece where you have resided the longest. $(\mathrm{F})$

Q3.3 Please rank the following factors based on their effect on reducing the aesthetic quality and attractiveness of the affected area after a wildfire, for the prefecture of Greece where you have resided the longest. (C)

Q3.4 How are you personally impacted when human health and lives are affected by a wildfire? (D)

Q3.5 How are you personally impacted when casualties of firefighting personnel occur during a wildfire? (D)

Q3.6 Which type of infrastructure damage or destruction that can happen during a wildfire can have the most profound negative effect on the prefecture of Greece where you have resided the longest? (E)

Q3.7 Which economic losses that can happen after a wildfire can have the most profound negative effect on the prefecture of Greece where you have resided the longest? (E) Q3.8 Rank the five wildfire effects questions from most (1) to least (7) important as to their contribution to describing overall wildfire effects. (C)

$\begin{array}{cccccccc} & & & & \text { F: Matrix, } & \text { G: Matrix, } & \text { H: Matrix, } \\ \text { A: Drill } & \text { B: Multiple } & \text { C: Ranking } & \text { D: Matrix, } & \text { E: Matrix, No } & \text { Not } & \text { No } & \text { Strongly } \\ \text { Down } & \begin{array}{c}\text { Choice: one } \\ \text { answer }\end{array} & \text { Order } & \text { Highest } & \text { Effect to Very } & \text { Important to } & \text { Experience to } & \text { Disagree to } \\ & & & \text { Impact } & \text { High Effect } & \text { Extremely } & \text { Very High } & \text { Strongly } \\ & & & & \text { Important } & \text { Experience } & \text { Agree }\end{array}$

\section{Results}

\subsection{Sample Structure and Information}

Survey respondents were mostly male, half between 35 and 54 years old, one-third working for the Fire Service, with $66 \%$ holding college degrees, and $45 \%$ considered experts based on wildfire experience (Table 2). Respondents that experienced more than 10 fires comprised $28 \%$ of all respondents, while $30 \%$ had experienced fewer than 2 fires, with half of all respondents experiencing more than 5 fires (Figure 2A). In terms of geographic distribution, $41 \%$ of respondents were from northern Greece, 32\% from one of the islands, and $27 \%$ from southern Greece. The corresponding percentages of the true country's population ( 2011 census) were $41 \%$ from northern Greece, $13 \%$ from the islands, and $46 \%$ from southern Greece. 
Table 2. Socio-demographic component results of the respondents with basic statistical metrics.

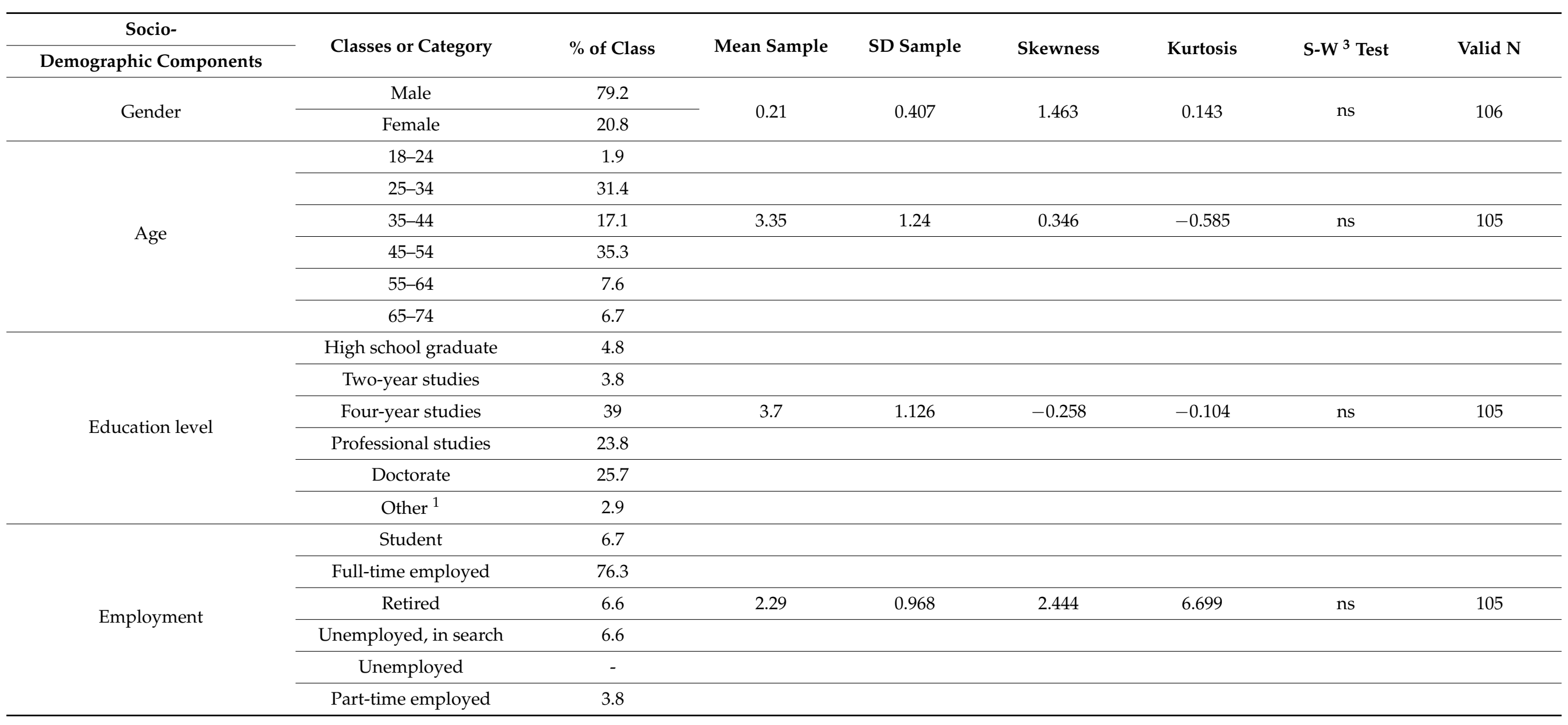


Table 2. Cont.

\begin{tabular}{|c|c|c|c|c|c|c|c|c|}
\hline $\begin{array}{c}\text { Socio- } \\
\text { Demographic Components }\end{array}$ & Classes or Category & $\%$ of Class & Mean Sample & SD Sample & Skewness & Kurtosis & S-W ${ }^{3}$ Test & Valid $\mathbf{N}$ \\
\hline \multirow{8}{*}{ Job condition } & Inactive $^{2}$ & 21 & & & & & & \\
\hline & Fire Service & 32.4 & & & & & & \\
\hline & Expatriate employees & 2.9 & & & & & & \\
\hline & Central Government & 11.4 & & & & & & \\
\hline & Private sector & 6.7 & 3.45 & 2.236 & 0.589 & -1.013 & ns & 105 \\
\hline & Research-University & 10.5 & & & & & & \\
\hline & Research-Government & 1.9 & & & & & & \\
\hline & Research-Private & 1 & & & & & & \\
\hline
\end{tabular}

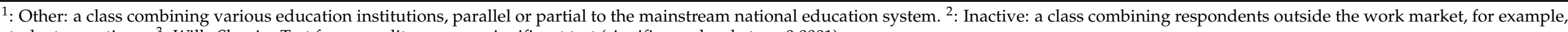
students or retirees. ${ }^{3}$ : Wilk-Shapiro Test for normality; ns: non-significant test (significance level at $p<0.0001$ ) 

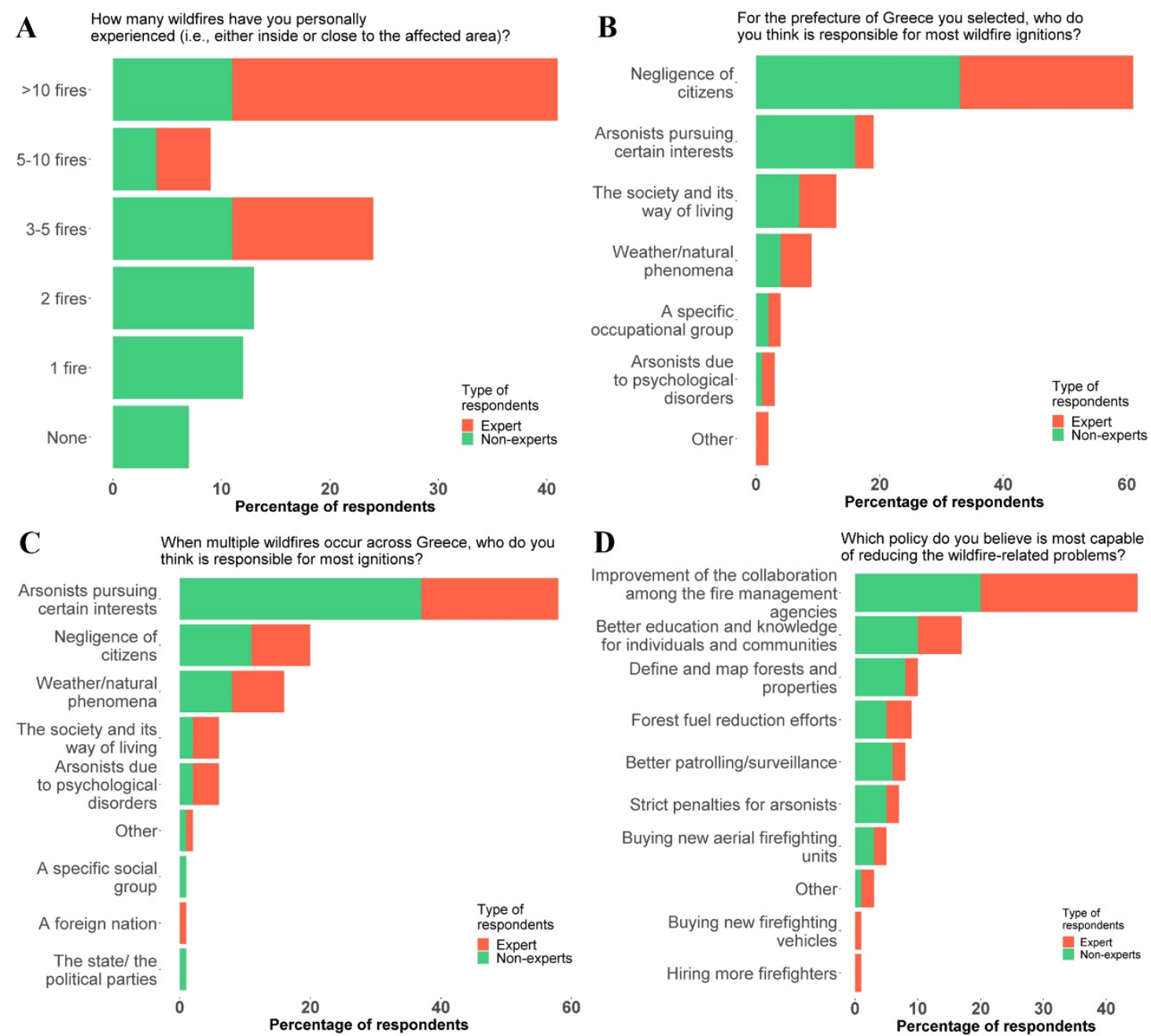

Figure 2. Survey response summary for three of the six general questions and one personal question. (A) How many wildfires have you personally experienced (i.e., either inside or close to the affected area)? (B) For the prefecture of Greece you selected, who do you think is responsible for most wildfire ignitions? (C) When multiple wildfires occur across Greece, who do you think is responsible for most ignitions? (D) Which policy do you believe is most capable of reducing the wildfire-related problems?

\subsection{General Perceptions on Fire Prevention and Management}

Most respondents believed that wildfire ignitions primarily occur due to the negligence of citizens, by arsonists pursuing specific objectives, or by the way the society/people in their home region function and live (Figure 2B). Only a minority of people (8\% of all responses) believed that ignitions occur due to natural causes such as lightning. When the question was framed differently, for instance, "When multiple wildfires occur across Greece, who do you think is responsible for most ignitions?" (Figure 2C), the respondents rated "arsonists pursuing specific interests" higher, while they attributed additional influence on weather/natural phenomena. Negligence of citizens was also rated high, while some respondents stated that arsonists with psychological disorders were those causing most wildfires.

Respondents believed that improved collaboration among the fire management agencies was the most suitable approach to reduce wildfire-related problems (Figure 2D), while better education and access to information for individuals and communities could play a major role in achieving this goal. There was limited support for fuel reduction programs, since only a small percentage of respondents $(9 \%)$ believed that fuel reduction activities 
could have an impact on wildfire frequency and behavior (Figure 2D). Responses related to increased fire suppression capacity (better patrolling or surveillance, acquisition of new firefighting resources, and hiring of more firefighters) received limited support as well (15\% of all responses).

Two controversial issues are apparent from the informant responses (i.e., some respondents accepted and some disapproved). The first is whether all fires, both planned and unplanned ignitions, must remain illegal, and the second is about the allowance of some natural fires to burn to achieve ecological objectives (Figure 3A), with relatively evenly divided percentages between acceptance and disapproval. The respondents were very hesitant about fire use without strict supervision and a training framework, although they overwhelmingly agreed (almost $80 \%$ ) on the need for tolerance and legal protection of people involved in a possible accident in the case of official use of fire. Almost $75 \%$ of respondents agreed that fire can effectively manage and protect forests, and that fire use is an inexpensive method for firefighting and the removal of unwanted fuels (about $65 \%$ ), but with strong minorities disagreeing on both issues (about $25 \%$ and $35 \%$, respectively). Strong minorities could be influential, especially on issues regarding fire and legislative reforms.

$\mathbf{A}$

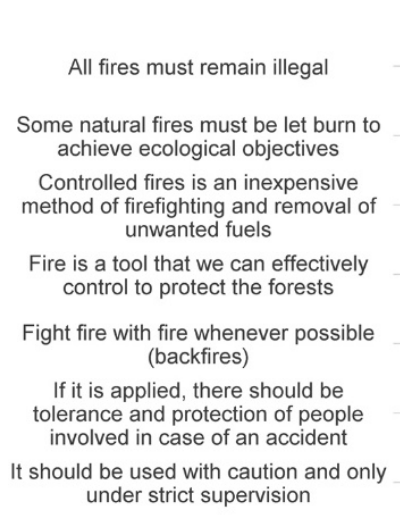

B

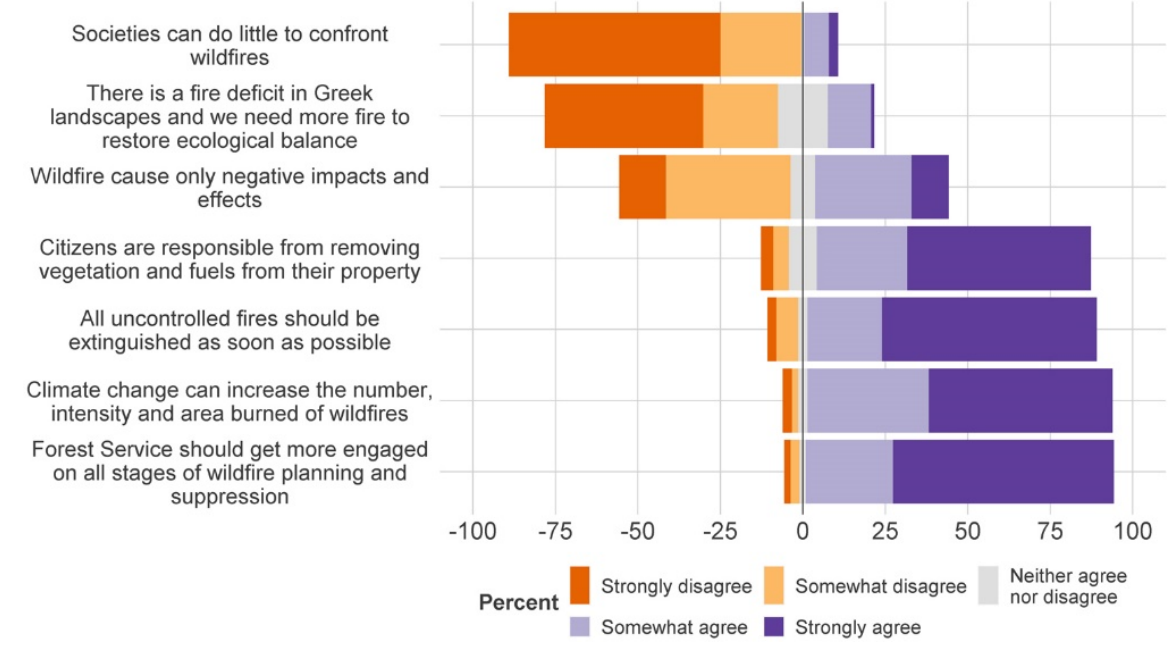

"What is your opinion on using controlled fire during firefighting or as prescribed fire to reduce forest fuels?"

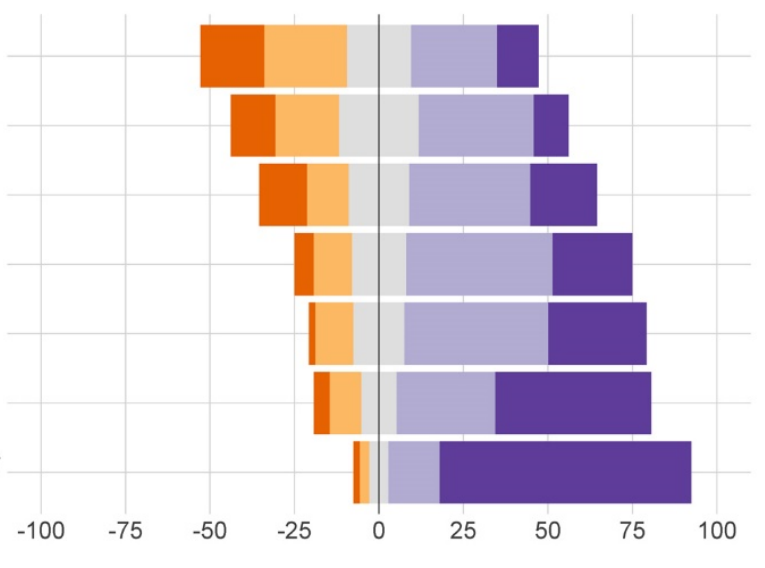

"What is your opinion on the specific wildfire-related statements?"

Figure 3. Likert scale responses for two of the six general survey questions regarding fire management. (A) What is your opinion on using controlled fire during firefighting or as prescribed fire to reduce forest fuels? (B) What is your opinion on the specific wildfire-related statements? 
The respondents overwhelmingly agreed that societies (i.e., a combination of citizen responsibility and way of living, community and local government actions, and central government legislation and interventions) can do much to confront wildfires (Figure 3B), a finding that was in accordance with the responses in Figure 2D, where most respondents believed that socially-related improvements can reduce wildfire-related problems (i.e., collaboration, education, and officially defined ownership boundaries). For these issues, minority responses were comprised mostly of non-experts. Almost $45 \%$ of the respondents stated that wildfires caused only negative impacts and effects (Figure 3B), with more than $75 \%$ disagreeing that there is a fire deficit in Greek landscapes due to the intense fire suppression of the past decades (i.e., the "fire paradox" phenomenon) [28] and the natural reforestation of formerly agricultural lands following land abandonment.

There was little tolerance for allowing wildfires to be managed for resource objectives under specific burning conditions, and the clear majority agreed that they should be extinguished as soon as possible. Resource objective wildfires are naturally ignited fires that are allowed to burn and play their natural role, that is, restoring degraded forests by reducing tree densities, fuel loading, and the potential for uncharacteristic crown fires; increasing understory abundance and species richness; and reestablishing landscape conditions more resilient to disturbances such as fire, insects, and drought $[29,30]$.

Regarding climate change, most of the respondents ( $>90 \%)$ agreed that it can increase the number, intensity, and area burned by wildfires. About $80 \%$ of the respondents agreed that it is the responsibility of citizens to remove vegetation and fuels from their property. The respondents also acknowledged that the Forest Service, which currently has little involvement, should become more engaged in all stages of wildfire planning and suppression.

We asked the respondents to rank eight factors, each describing how they understood and perceived the complexity of fire suppression (Figure 4). The responses were converted into the percentages of participants that ranked each factor as Very High (Rank 1 or 2), High (Rank 3 or 4), Low (Rank 5 or 6), and Very Low (Rank 7 or 8). People perceived the high number of firefighting aircraft and personnel (more than 65,000 people are involved each year) as a major factor to understand if a wildfire is evolving to become a high intensity/large fire event. In contrast, international firefighting crews invited to assist local firefighting forces and the declaration of the affected area under a state of emergency had the least influence. Another important factor was the ignition of new fires through spotting. Settlement evacuation and extreme fire behavior (e.g., crown fires) had equal percentages among the Very Low/Low and High/Very High response groups.

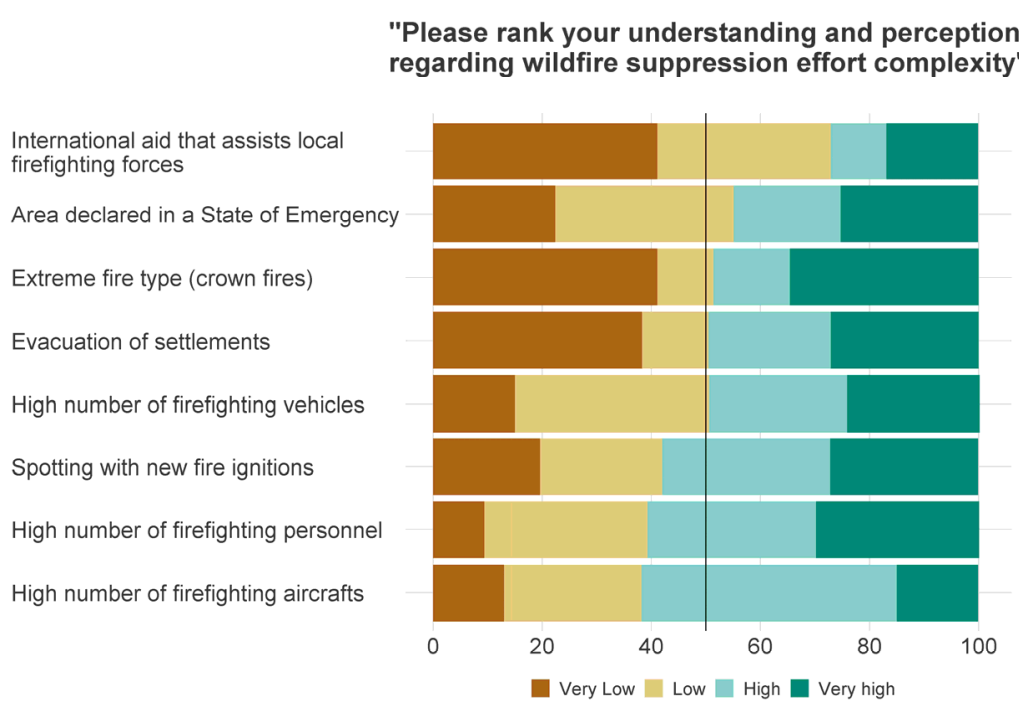

Figure 4. Likert scale ranking of factors that affect wildfire suppression complexity as percentages of survey responses. 


\subsection{Perceptions on Post-Fire Effects}

Most of the respondents believed that illegal activities and land-use changes within burned areas were the major drivers that halted natural regeneration ( $>50 \%$ recognized a High and Very High effect) (Figure 5A). Post-fire grazing was the second most important factor for vegetation recovery failures. Other important factors that negatively affect natural regeneration, according to the respondents, were subsequent fire activity inside the affected area and steep burned slopes. Most respondents also acknowledged the negative role of fire on vegetation during its non-reproductive age. Urban and tourism pressures on burned areas were generally considered to be a negative factor to regeneration, although a significant percentage disagreed on this.

A

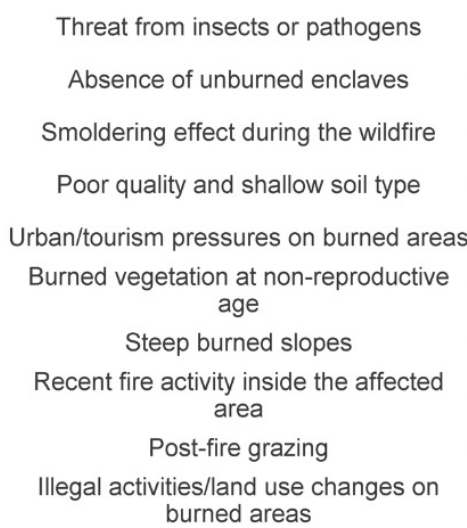

The wildfire burned inside WUI/urban forested parks, scenic mountainous areas or popular vantage points

\section{"Effect on regeneration and vegetation recovery potential after a wildfire"}

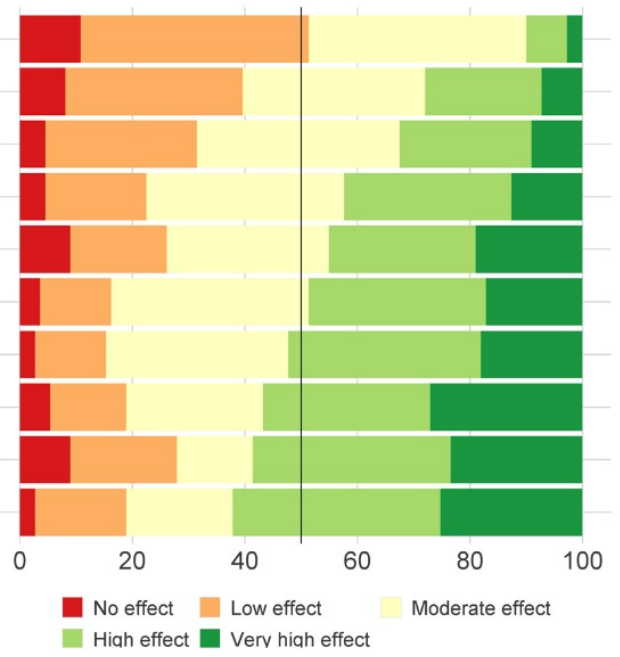

"Effect on reducing the aesthetic quality and attractiveness of the wildfire affected area"

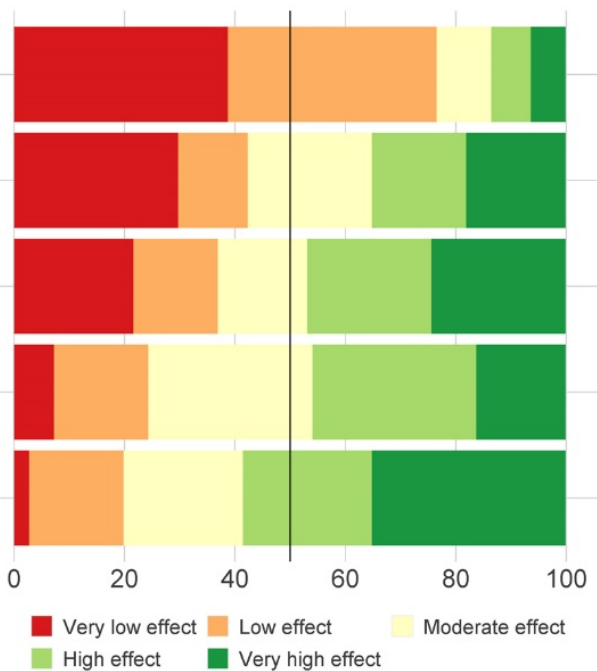

Figure 5. Likert scale rating of the importance of wildfire effects as a percentage of survey responses on the following: (A) regeneration and vegetation recovery potential; (B) factors that negatively affect aesthetic quality and attractiveness within areas burned by wildfire.

The second post-fire effects question comprised five factors, each describing a negative effect on the aesthetic quality and attractiveness of the wildfire affected area (Figure 5B). The responses were converted into the percentages of participants that ranked each factor as Very High (Rank 1), High (Rank 2), Moderate (Rank 3), Low (Rank 4), and Very Low effect 
(Rank 5). The proximity of a wildfire to the WUI, urban forested parks, scenic mountainous areas, or popular view vantage points was ranked as having the highest effect for most respondents $(>60 \%)$, followed by the type of forest and vegetation that burned, especially those considered visually and aesthetically attractive. Another important consideration was post-fire soil-related events, which can have important consequences (e.g., floods, landslides, low aesthetic quality) and influence on the properties and livelihood of the populations in proximity to the fire-affected areas $(>45 \%$ of all respondents ranked it with High or Very High effect). Smoke was not an important issue (Very Low or Low effect) for more than $75 \%$ of the respondents. Surprisingly, more than $40 \%$ of the respondents valued the fire effects on protected lands as Very Low or Low.

In terms of the environmental effects of wildfire (Figure 6), $55 \%$ of the respondents considered the loss of endangered, rare, or important vegetation species as very or extremely important. Habitat loss of endangered, rare, or important bird species was rated second in importance (47\% rated such losses as Very or Extremely important). Local communities are positively affected by tourism and recreational activities, such as bird watching around the 196 Important Bird and Biodiversity Areas of Greece that host important native and migratory bird populations. Several rare plants in Greece with spatially isolated, low population numbers face wildfires as a threat to their existence, especially when combined with other pre- or post-fire disturbances. A total of 10 of the 50 most endangered/vulnerable plant species in the Mediterranean are recorded in Greece [31].

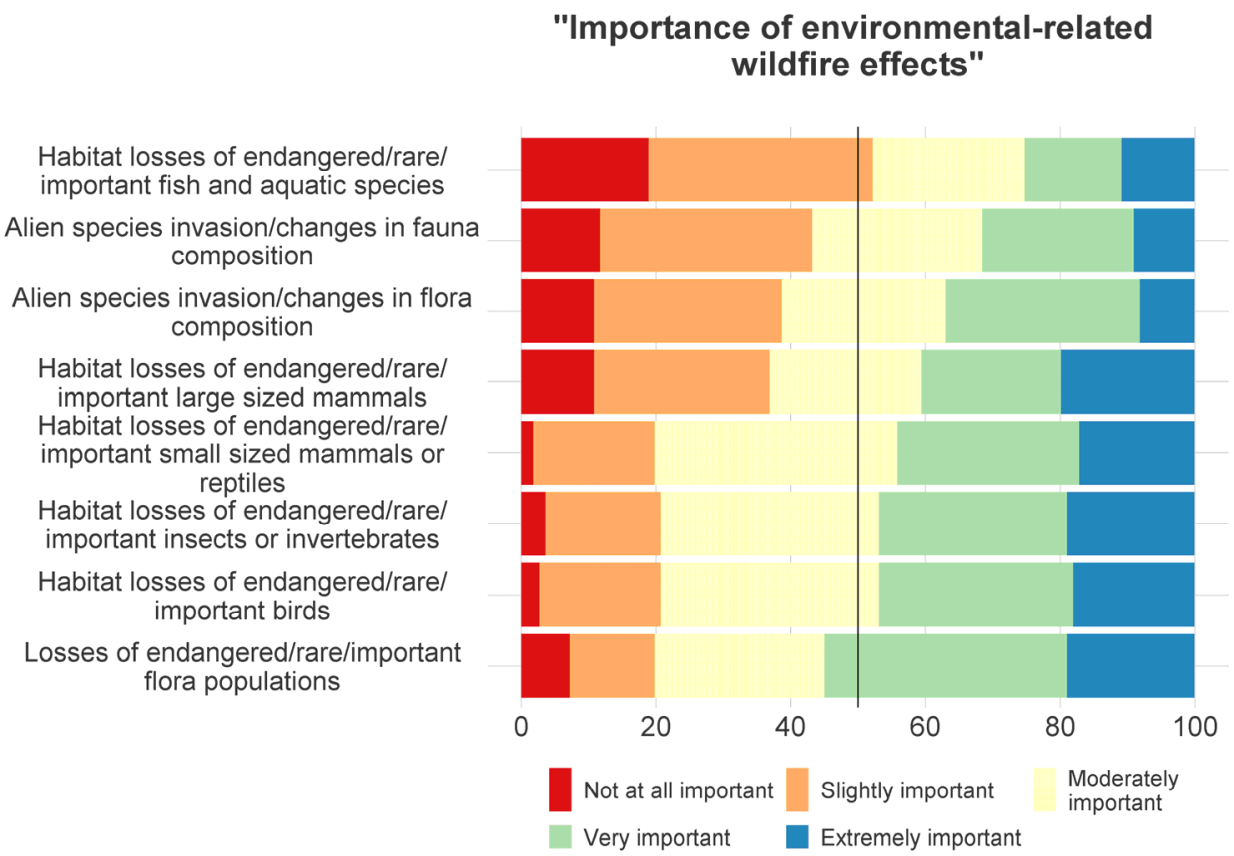

Figure 6. Likert scale rating of factors that negatively affect habitat or endangered/rare/important species population within areas burned by wildfire, as a percentage of survey responses.

Insect or invertebrate populations were also considered as Very or Extremely important, followed by smaller-sized mammals or reptiles. There are examples of insects and invertebrates species at a high risk of extinction in case of an intense wildfire, like the Panaxia quadripunctaria butterfly on Rhodes island [32], with a population in a small forested valley visited by thousands of tourists each year. The respondents had less interest in fire effects on important fish and aquatic species. Most respondents considered the invasion of alien fauna and flora species as the Least important (40\%).

The fourth question comprised 11 factors, each describing different infrastructure damage or destruction caused by wildfire (Figure 7A). The effect on residential buildings (homes and hotels) was rated as the most important $(>70 \%$ of respondents acknowledged it as High or Very High); damage to utility networks (water, power, and telecommunication) 
was rated among the five most important factors, with more than $60 \%$ rating them as High or Very High effect. Wildfire effects on cultural heritage monuments, including religious sites and structures, were rated as the fourth most important factor. Damages to military equipment, ammunition, and facilities received mostly Moderate to Low answers. Damages to private vehicles, machinery, and mechanical equipment had slightly more responses for High to Very High compared to Low or No effect. More than $20 \%$ of all respondents stated that damages to roads and public transportation networks will have only Low or No effect. Other highly important factors included damages to agricultural or livestock infrastructure, followed by industrial buildings, and renewable energy infrastructure. Damages to household stables, warehouses, and auxiliary buildings were evaluated as Moderate to High.

A

Military equipment, ammunition,
facilities
Private vehicles, machinery and
mechanical equipment
Household stables, warehouses, auxiliary
buildings
Roads and public transportation network
Industrial buildings or renewable energy
infrastructure
Agricultural or livestock infrastructure
Telecommunications network
Cultural heritage monuments or sites
Water supply network
Power network
Houses/hotels

B
Lost revenue from burnt or delayed harvest of logging and wood products
Lost revenue from burnt or extinct non- wood forest products
Lost revenue from burnt or reduced livestock production
Lost revenue from burnt or delayed harvest of agricultural production
Lost revenue from tourism and recreational activities
Post-fire restoration costs of
infrastructure, public property and industries
Post-fire restoration costs of houses and private structures
Post-fire restoration costs of landscape - reforestation - flood prevention

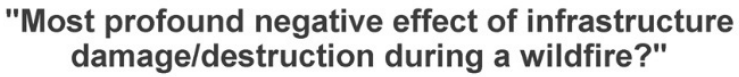
damage/destruction during a wildfire?"

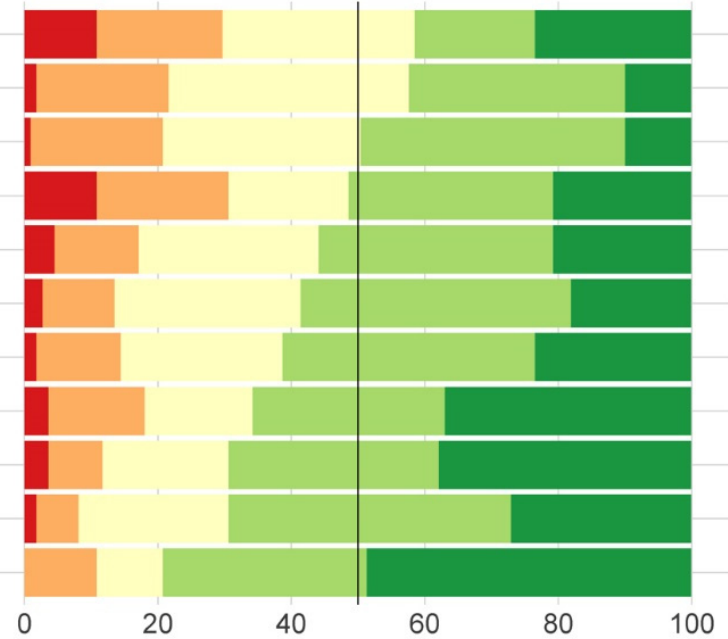

"Most profound wildfire-related economic loses"

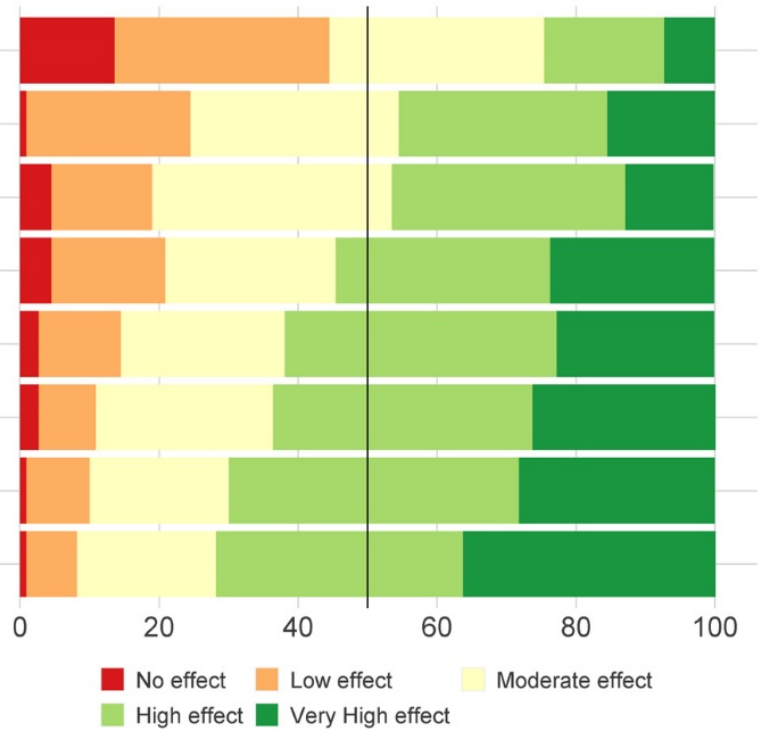

Figure 7. Likert scale rating of factors that cause (A) negative wildfire effects on infrastructure; (B) wildfire-related economic losses, expressed as a percentage of responses from survey results.

The last question evaluated the post-fire economic losses through eight factors (Figure 7B). In general, post-fire restoration costs were considered as the most important, followed 
by houses and private structures. Compensation or reparations for infrastructure, public property, and industries are common after most wildfires and was the third most important factor since these costs can be very high. Lost revenue from tourism and recreational activities was rated fourth. More than $40 \%$ answered that they considered the lost revenue from burned or delayed harvest of logs and wood products to have Low or No effect. More than $20 \%$ considered that the lost revenue from burned or post-fire absence of non-wood forest products have a Low effect, but the majority considered it as important $(>50 \%$ of all respondents). Lastly, lost revenue from reduced harvest of agricultural products or livestock production was considered to have a High or Very High effect $(>50 \%)$.

\subsection{Differences Between Expert and Non-Expert Respondents}

We found differences in the way experts and non-experts rated specific factors related to questions, reflecting their divergent approaches to fire management, policy strategies, and fire effects (Figure 8). We compared the percentages of responses within ratings received for each question between the experts and non-experts; for example, if $50 \%$ of experts rated a question highly vs. $40 \%$ of non-experts for the same question and response, then the difference is $10 \%$. Only differences greater than $10 \%$ were kept and considered as a discernible cut-off point. We were interested in only those questions that had differences in the assessment of what was considered to be of high importance for each group, that is, the responses characterized as Somewhat Strongly Agree, Very or Extremely important, and High or Very High effect.

Experts were more in favor of backfire use and had a stronger belief that controlled fires can be used as a forest management/protection tool (Figure 8A). Also, proportionally, more experts $(18 \%)$ suggested that better collaboration among fire management agencies should be pursued, and that citizens should be responsible for removing vegetation and fuels from their property $(16 \%)$. In addition, experts believed more that there should be tolerance and protection of people involved in prescribed fire accidents (14\%). In terms of fire effects, more experts rated the lost revenue from burned or delayed harvest of agricultural production and the loss of agricultural and livestock infrastructure higher. In addition, they rated the effect of steep slopes higher in natural regeneration and the extreme fire type as complicating fire suppression activities.

More non-experts believed that arsonists set fires to achieve specific objectives, either for their local community or for the entire country, with $18 \%$ more supportive of the statement that wildfires cause only negative impacts and effects, and $12 \%$ more supportive of the statement that all fires must remain illegal (Figure 8B). They also believed that illegal activities and land-use changes are responsible for reduced regeneration on the affected areas more frequently than experts. In addition, $18 \%$ more non-experts evaluated the destruction of industrial buildings and renewable energy infrastructure as important. Finally, non-experts considered the evacuation of settlements and the high number of firefighting personnel more important in indicating fire suppression complexity. 


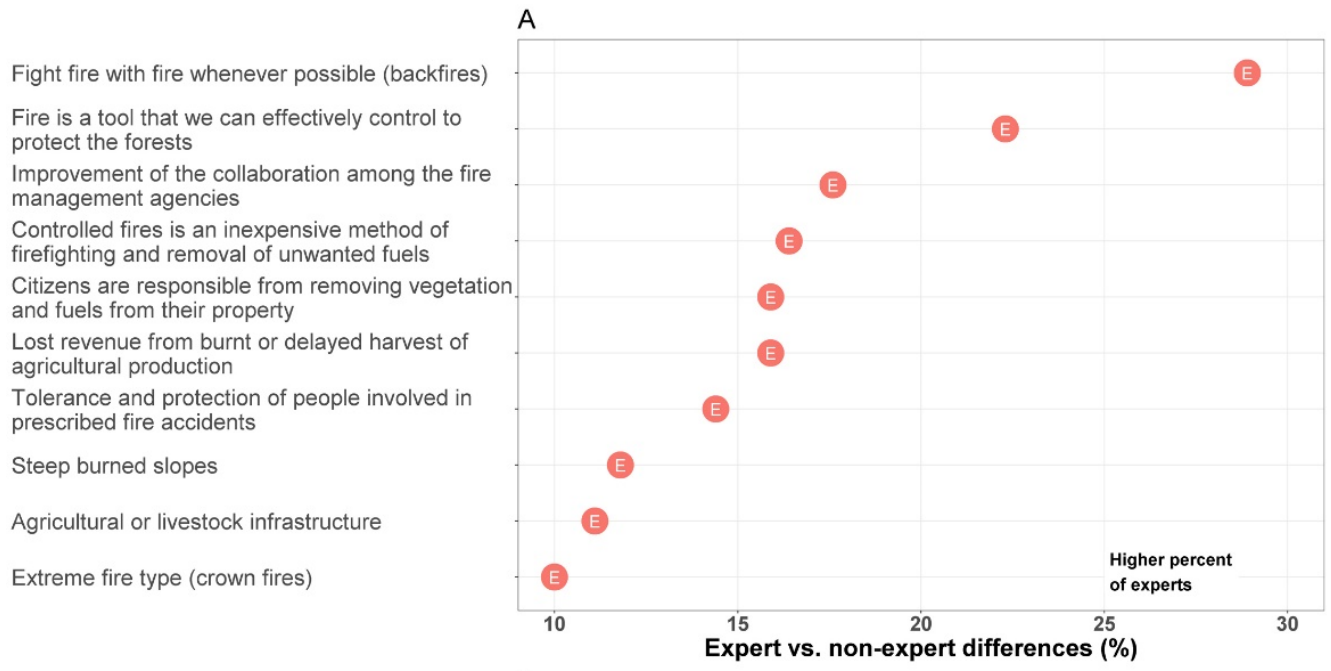

Arsonists pursuing certain interests (Local)

Industrial buildings or renewable energy infrastructure

Wildfire cause only negative impacts and effects

Arsonists pursuing certain interests (Greece)

Post-fire restoration costs of infrastructure, public property and industries

Illegal activities/land use changes on burned areas

Evacuation of settlements

Habitat losses of endangered/rare/important large sized mammals

All fires must remain illegal

High number of firefighting personnel

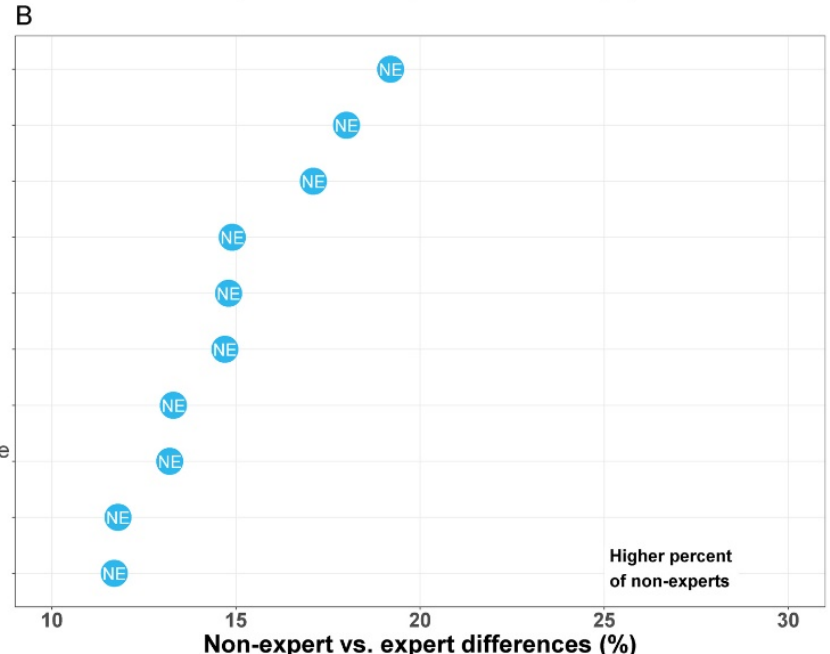

Figure 8. Percentage differences in the number of responses for different ratings of questions for those respondents characterized as experts relative to non-experts (A) and non-experts relative to experts (B). The number of respondents that answered each question with Somewhat or Strongly Agree, Very or Extremely important, and High or Very High effect were summed by respondent class (i.e., experts relative to non-experts) and converted to percentages from the total of each class. Experts are described with a red "E" point and non-experts with a blue "NE" point. Note that only strong differences ( $>10 \%$ of the number of respondents for each group) are shown.

\section{Discussion and Conclusions}

To our knowledge, this is the first country-wide, wildfire-focused social study after the disastrous 2007 wildfires in Greece that had a deep impact on how society, fire professionals, and political entities understand wildfire management and effects. Our analysis revealed multiple obstacles to improving wildfire risk governance in Greece, originating from long-established views about wildfires, which may support, validate, and/or contradict previous, related research [19-22,33]. Key barriers include landscape fragmentation, legal barriers for wildland fire use and prescribed fire, weak collaboration among the major stakeholders and agencies, weak acceptance of fuel management as a fire management strategy, a lack of funds, and a lack of knowledge on the spatial scale of fire risk, that is, where fires start, how they spread, and who or what can potentially be affected (fire effects).

We identified a few limitations of our study, including the relatively small sample size, the under-representation of women, the low participation of people working for the Forest Service, and the uneven representation of the population of southern Greece (underrepresentation) and islands (over-representation). The under-representation of women 
may be explained by the lower number of female firefighters in the Greek Fire Service and their lower level of involvement in wildfire-related studies in research organizations and universities [34]. Although the questionnaire was distributed across all fire-related agencies and organizations of Greece, the increased response rate from northern Greece and the islands might be independent or random due to pure geography or biases through personal connections with the University of the Aegean that coordinated this study.

The results revealed that the respondents generally had a negative attitude towards using naturally ignited fires to achieve resource management objectives [35], and expressed a strong belief that wildfires only cause adverse impacts, especially among non-expert respondents. We found no consensus on whether fire has a natural role in the Greek landscape. Overall, the landscape is highly fragmented and rarely without some sort of human intervention or activity, so any fire has the potential to burn into scattered private properties where people, homes, infrastructure, or other values are at risk (e.g., ecologically important habitats, historically significant cultural sites). The respondents strongly agreed that all wildfires should be extinguished as soon as possible, with only weak support to legitimize some fires for resource objectives under specific conditions [29].

On the other hand, the respondents indicated a slightly positive attitude for controlled fires under specific conditions where highly trained fire suppression crews can strictly control their spread. Backfires are gaining acceptance among the public, mostly because of the successful "silent" implementation from firefighting crews from other European Union countries that came to help the Greek firefighters during the 2007 extreme fire season [36]. The respondents who identified as experts are more favorable towards backfires, considering controlled fires as an effective and inexpensive method of firefighting and removal of unwanted fuels. However, the largely neutral responses on fire use revealed in our survey highlight an important opportunity to educate the public on the beneficial uses of fire in the landscape.

We expect that substantial legal reforms to allow fire to be used as a tool during fire suppression and fuel management will encounter strong opposition despite the clear benefits, as established in research elsewhere [30]. Fire suppression in Greece is anachronistic, using machinery to clear vegetation in the path of an upcoming fire front or directly throwing water by land or air to suppress the flames. Backfires can revolutionize the way fire suppression is conducted and can produce measurable outcomes in terms of annual burned area reduction. In the work of Xanthopoulos [33], a literature review of past applications of backfires in Greece, including informal cases of backfire application during the 21st century, showed a lack of clear evidence on whether there is wide acceptance in the science community within Greece. In addition to our knowledge, public discussions on fire-related issues do not emphasize the need for legal reform on allowing backfires.

Reintroducing fire as a management tool may be an important strategy in resolving several ecological and management challenges on the Greek landscape in a cost-effective way. The training of GFS personnel and communication of the results from successful fuel management projects in Europe and elsewhere may encourage the agency and political leaders to allocate fuel management funds in the right places and at the right scale to change current wildfire behavior and reduce negative fire effects. All of the above lead to the rejection of our first hypothesis that the use of prescribed fire lacks even minimal support, since we found strong approval from respondents for backfires and prescribed fire as a management tool, but not the use of fire for resource objectives.

Most respondents, especially those characterized as experts, believed that the most effective wildfire management policies must deal with the way society and agencies function and interact. Policies that promote the enhancement of fire suppression (patrolling and strict penalties for arsonists, buying new firefighting vehicles, hiring additional personnel) received lower preference compared to other available options. These results lead to the rejection of our second hypothesis that stakeholders perceive wildfire suppression policies more favorably compared to preventive fire management. 
Despite the strong belief that arsonists are behind most ignitions, especially among non-expert respondents, citizen negligence accounts for more ignitions at local spatial scales. For example, the mass media, the Greek government, and public perception all indicated that arsonists were behind the 2007 wildfires, promoting real estate and industrial complex interests through fire terrorism (e.g., the Ministry of Public Order issued a bounty of a million euros on information that can lead to the arrest of the suspected crime organization that was behind these fires; order: FEK 1708/B/26.8.2007) [37,38]. In addition, a common misconception in the public and through media coverage of wildfire events is that they confuse spotting from fire fronts as new ignitions. Our understanding is that the lack of proper education regarding how wildfires spread is causing this confusion. Spotting concurrently ignites new fires in various locations in the periphery or ahead of the fire front and increases suppression complexity. This is mistakenly considered as the work of arsonists; for instance, during a government press conference (during the wildfires of 2007), it was stated that new ignitions after sunset resulted from an arsonist conspiracy [39], although evidence and observations suggested that spotting was very intense [40].

The respondents acknowledged that the lack of a national cadaster and the fuzzy boundaries among land ownerships are major sources of wildfire-related problems. The lack of a national cadaster delineating ownership has led landowners in the past to intentionally use fire to encroach illegally on public or disputed forested lands. During the 1990s and 2000s, there was strong pressure from local residents to convert shrub or sparsely reforested lands near WUI areas of high real estate value into either agricultural lands (often as an intermediate step) or high amenity/value residential areas [41].

The respondents were very concerned when the quality of everyday life on the affected lands was altered and reduced, especially if the fires resulted in burned houses and destroyed or damaged utility networks. This is reflected in state policies in several cases (e.g., after the devastating 2007 wildfires), where most of the restoration costs (up to USD 15,000 available to each affected family for house restoration) are covered by the state, adding an additional burden to the national and regional economy. Complimentary to the previous findings, higher importance was given when a wildfire burned closer to the WUI or to aesthetically attractive landscapes, in contrast to important ecological or natural places, for example, protected lands. Inferred from this finding, we expect low social pressure for post-fire rehabilitation in sparse shrub vegetation, grasslands, or common tree species burned or distant to populated areas with a low number of visits [23,38]. Usually, these actions include the construction of dams, anti-erosion barriers along the slopes (e.g., with burned logs or branches), the creation of terraces, salvage logging, and reforestation through the planting of conifer seedlings (e.g., 14,500 ha in 2001-2011), all conducted under the supervision of the GFS in collaboration with local authorities.

A drop in the landscape's aesthetic quality, emitted smoke, damaged infrastructure, and concern regarding future wildfire events can all negatively influence tourist visitation. Previous research suggested that the localized impact of forest fires can be felt for a number of years, but on a national level, especially when the tourism product is diverse, the impact in terms of the number of tourist visits and income lasts for a short period [35]. Studies in the United States showed that the leisure and hospitality services sector experienced negative impacts from wildfires on employment growth rates in non-metropolitan recreational or smaller economy counties [42,43]. Another interesting finding is the low importance given for smoke effects, probably due to the strong annual summer winds that can rapidly disperse a fire plume, especially from ignitions around the Aegean basin [44,45]. This contrasts with the wildfire emissions management applied elsewhere in the developed world, where smoke-related economic costs and health effects are considered to be extremely important $[46,47]$.

The respondents highlighted some profound issues affecting post-fire forest regeneration and vegetation recovery potential. Illegal activities (emphasized by non-experts), grazing, land-use changes, and topography were rated with high influence and can inform how post-fire management should be prioritized. It is well documented that in Greece, 
natural regeneration can be affected by unconstrained grazing, especially from goats and sheep, usually exceeding the carrying capacity of the land and eliminating seedlings and re-sprouts that, in turn, increase land degradation [14,48]. Despite the fact that most low elevation conifers and shrubs can regenerate quite well in poor soils and on gentle slopes [49,50], steep slopes can negatively influence post-fire regeneration, and evidence from previous studies [51] suggests that conifer seeds can be washed away downslope by strong rain events immediately following the fire. Finally, respondents believed that climate change alters current wildfire frequency and behavior, and this finding is in agreement with other studies (e.g., 85\% of Greeks accept that climate change is a very serious natural and social problem) [52].

Peoples' perceptions in a democracy can influence and shape the government's decisions on the most important social and environmental issues, but raising awareness of the threats, challenges, and solutions for these issues is often missing from public discourse. Taking actions that motivate the adoption of pro-environmental behaviors, with preliminary implementation in public education efforts is an important first step [53]. Furthermore, incorporating social and cultural values into environmental decision-making could help develop efficient fire risk assessment and hazard management strategies. In particular, determining which elements of a problem or a solution resonates best with different public sections can provide vital information for shaping effective fire management efforts and tailor relevant programs to fit social needs best [54]. Negative views on some policy change reforms (e.g., fire use) warrant improved education and informational campaigns that will showcase success stories while seeking active community involvement in the decisionmaking process. Engaging local communities as key players in the fire management planning and implementation process often improves outcomes [55,56]. We anticipate that the respondents' views and beliefs in this study can either represent the current established policies or carry a factor of change, reflecting the new economic, environmental, and social realities, or scientific advancements occurring across Europe and North America.

Supplementary Materials: The following are available online at https://www.mdpi.com/article/10 .3390 / fire4020018/s1: Transcript and detailed breakdown of the questionnaire used in this research, as compiled with Qualtrics.

Author Contributions: Conceptualization, P.P., K.K. and M.N.-P.; methodology, P.P. and M.N.-P.; validation, M.A.D., A.A.A., A.T. and K.K.; writing-original draft preparation, P.P.; writing—review and editing, A.A.A., M.A.D., A.T. and K.K.; funding acquisition, A.A.A. All authors have read and agreed to the published version of the manuscript.

Funding: This research was funded by the USDA Forest Service International Programs, grant number G-3-10895.

Acknowledgments: We would like to thank John Bailey and the Forest Engineering, Resources and Management department of the Oregon State University for their administrative and technical support to accomplish this research.

Conflicts of Interest: The authors declare no conflict of interest.

\section{References}

1. Palaiologou, P.; Ager, A.A.; Nielsen-Pincus, M.; Evers, C.; Kalabokidis, K. Using transboundary wildfire exposure assessments to improve fire management programs: A case study in Greece. Int. J. Wildland Fire 2018, 27, 501-513. [CrossRef]

2. Greek Government. The 2020 Greek Forest Service Budget, YPEN/DPDP/53540/1554/05.06.2020. Available online: https: / / diavgeia.gov.gr/doc/\%CE\%A8\%CE\%9B\%CE\%A6\%CE\%9A4653\%CE\%A08-\%CE\%95\%CE\%98\%CE\%9A?inline=true (accessed on 7 July 2020).

3. Greek Government. The 2020 Local Government Budget for Wildfire Protection, $\Omega$ KГ $\triangle 46 \mathrm{MT} \Lambda 6-\mathrm{N} \Sigma 2 / 26258$. Available online: https:/ /diavgeia.gov.gr/doc/\%CE\%A9\%CE\%9A \%CE $\% 93 \% C E \% 9446 \% C E \%$ C $\% C E \% A 4 \% C E \% 9 B 6-\% C E \% 9 D \% C E \% A 3$ 2?inline=true (accessed on 7 July 2020).

4. Kalabokidis, K.; Palaiologos, P.; Xanthopoulos, G. Pyro-geography of the Greek landscape. In The Geography of Greece: Managing Crises and Building Resilience; Darques, R., Ed.; Springer: Dordrecht, The Netherlands, in press. 
5. EFFIS. European Forest Fire Information System, Joint Research Centre: Forest Fires in Europe, Middle East and North Africa; European Commission, Publications Office: Luxembourg, 2020.

6. Palaiologou, P.; Kalabokidis, K.; Ager, A.A.; Day, M.A. Development of comprehensive fuel management strategies for reducing wildfire risk in Greece. Forests 2020, 11, 789. [CrossRef]

7. Goupos, C.; Papastaurou, C. Legal restrictions on forest ownership in Greece. In Forging a New Framework for Sustainable Forestry: Recent Developments in European Forest Law; IUFRO World Series; ETH: Zurich, Switzerland, 2000; Volume 10, pp. 156-161.

8. Benayas, J.R.; Martins, A.; Nicolau, J.M.; Schulz, J.J. Abandonment of agricultural land: An overview of drivers and consequences. CAB Rev. Perspect. Agric. Vet. Sci. Nutr. Nat. Resour. 2007, 2, 1-14. [CrossRef]

9. MacDonald, D.; Crabtree, J.R.; Wiesinger, G.; Dax, T.; Stamou, N.; Fleury, P.; Gutierrez Lazpita, J.; Gibon, A. Agricultural abandonment in mountain areas of Europe: Environmental consequences and policy response. J. Environ. Manag. 2000, 59, 47-69. [CrossRef]

10. Zakkak, S.; Kakalis, E.; Radović, A.; Halley, J.M.; Kati, V. The impact of forest encroachment after agricultural land abandonment on passerine bird communities: The case of Greece. J. Nat. Conserv. 2014, 22, 157-165. [CrossRef]

11. Tedim, F.; Xanthopoulos, G.; Leone, V. Chapter 5-Forest fires in Europe: Facts and challenges A2. In Wildfire Hazards, Risks and Disasters; Paton, D., Shroder, J.F., Eds.; Elsevier: Oxford, UK, 2015; pp. 77-99. [CrossRef]

12. Cavounidis, J. Migration and the economic and social landscape of Greece. South East. Eur. J. Econ. 2013, 11, 59-78.

13. Salvati, L. Bridging the divide: Demographic dynamics and urban-rural polarities during economic expansion and recession in Greece. Popul. Space Place 2019, 25, e2267. [CrossRef]

14. Arianoutsou, M. Landscape changes in Mediterranean ecosystems of Greece: Implications for fire and biodiversity issues. J. Mediterr. Ecol. 2001, 2, 165-178.

15. Thompson, K. Farm Fragmentation in Greece: The Problem and Its Setting: With 11 Village Case Studies; C. Serbinis Press: Athens, Greece, 1963; p. 263.

16. Kasimis, C.; Venturas, L.; Ziomas, D. Greece: Social Impact of Emigration and Rural-Urban Migration in Central and Eastern Europe; European Commission: Brussels, Belgium, 2012; p. 3.

17. Close, D.H. Greece since 1945: Politics, Economy and Society; Routledge: Oxfordshire, UK, 2014.

18. Tsilimigkas, G.; Kizos, T. Space, pressures and the management of the Greek landscape. Geogr. Ann. Ser. B Hum. Geogr. 2014, 96, 159-175. [CrossRef]

19. Henderson, M.; Kalabokidis, K.; Marmaras, E.; Konstantinidis, P.; Marangudakis, M. Fire and society: A comparative analysis of wildfire in Greece and the United States. Hum. Ecol. Rev. 2005, 12, 169-182.

20. Kalabokidis, K.; Iosifides, T.; Henderson, M.; Morehouse, B. Wildfire policy and use of science in the context of a socio-ecological system on the Aegean Archipelago. Environ. Sci. Policy 2008, 11, 408-421. [CrossRef]

21. Morehouse, B.J.; Henderson, M.; Kalabokidis, K.; Iosifides, T. Wildland Fire Governance: Perspectives from Greece. J. Environ. Policy Plan. 2011, 13, 349-371. [CrossRef]

22. Papanikolaou, V.; Adamis, D.; Mellon, R.C.; Prodromitis, G.; Kyriopoulos, J. Trust, social and personal attitudes after wildfires in a rural region of Greece. Sociol. Mind. 2012, 2, 87. [CrossRef]

23. Xanthopoulos, G. People and the mass media during the fire disaster days of 2007 in Greece. In Proceedings of the International Bushfire Research Conference Fire, Environment and Society, Adelaide, Australia, 1-3 September 2008; p. 14.

24. EEA. Corine Land Cover (CLC) 2018; Version 2020_20u1; 12 July 2013; European Environment Agency: Copenhagen, Denmark, 2018.

25. Papanastasis, V.P.; Mantzanas, K.; Dini-Papanastasi, O.; Ispikoudis, I. Traditional agroforestry systems and their evolution in Greece. In Agroforestry in Europe: Current Status and Future Prospects; Rigueiro-Rodróguez, A., McAdam, J., Mosquera-Losada, M.R., Eds.; Springer: Dordrecht, The Netherlands, 2009; pp. 89-109.

26. Tsagari, K.; Karetsos, G.; Proutsos, N. Wildfire in Greece, 1983-2008; WWF Hellas and NAGREF: Athens, Greece, $2011 ;$ p. 112.

27. Qualtrics, Qualtrics, Provo, Utah, USA. 2018. Available online: https:/ / www.qualtrics.com/blog/citing-qualtrics / (accessed on 1 April 2021).

28. Ingalsbee, T. Whither the paradigm shift? Large wildland fires and the wildfire paradox offer opportunities for a new paradigm of ecological fire management. Int. J. Wildland Fire 2017, 26, 557. [CrossRef]

29. Berger, C.; Fitzgerald, S.; Leavell, D. Managing wildfire for resource benefit: What is it and is it beneficial? In Fire FAQs; Oregon State University Extension Service: Corvallis, OR, USA, 2018.

30. Huffman, D.W.; Roccaforte, J.P.; Springer, J.D.; Crouse, J.E. Restoration applications of resource objective wildfires in western US forests: A status of knowledge review. Fire Ecol. 2020, 16, 1-13. [CrossRef]

31. De Montmollin, B.; Strahm, W. The Top 50 Mediterranean Island Plants: Wild Plants at the Brink of Extinction, and What Is Needed to Save Them; De Montmollin, B., Strahm, W., Eds.; IUCN: Gland, Switzerland; Cambridge, UK, 2005.

32. Pamperis, L.N. The Butterflies of Greece; Bastas-Plessas Graphic Arts SA: Athens, Greece, 1997.

33. Xanthopoulos, G.; Athanasiou, M.; Kazakis, G.; Ghosn, D.; Kaoukis, K. Backfire and its use in Greece. In Proceedings of the 19th Greek Forestry Conference, Litochoro, Greece, 29 September-2 October 2019; pp. 255-267.

34. Smith, A.M.S.; Strand, E.K. Recognizing Women Leaders in Fire Science: Revisited. Fire 2018, 1, 45. [CrossRef]

35. Boustras, G.; Boukas, N. Forest fires' impact on tourism development: A comparative study of Greece and Cyprus. Manag. Environ. Qual. 2013, 24, 498-511. [CrossRef] 
36. Xanthopoulos, G.; Athanasiou, M.; Zirogiannis, N. Use of fire for wildfire suppression during the fires of 2007 in Greece. In Proceedings of the 2nd International Conference on Fire Behaviour and Risk, Sardinia, Italy, 26-29 May 2015; pp. 26-29.

37. Tsaliki, L. Technologies of political mobilization and civil society in Greece: The wildfires of summer 2007. Convergence 2010, 16, 151-161. [CrossRef]

38. Hovardas, T. "Playing with Fire" in a Pre-Election Period: Newspaper Coverage of 2007 Wildfires in Greece. Soc. Nat. Resour. 2014, 27, 689-705. [CrossRef]

39. Hovardas, T. An "Asymmetric Threat" That Should Have Been Anticipated: Political Discourse on 2007 Wildfires in Greece. Environ. Commun. 2015, 9, 409-427. [CrossRef]

40. Xanthopoulos, G.; Viegas, D.X.; Caballero, D. The fatal fire entrapment of Artemida (Greece) 2007. In Recent Forest Fire Related Accidents in Europe; Viegas, D.X., Ed.; Office for Official Publications of the European Communities: Luxembourg, 2009; EUR 24121 EN; pp. 65-75.

41. Papanastasis, V.P.; Kazaklis, A. Land use changes and conflicts in the Mediterranean-type ecosystems of western Crete. In Landscape Disturbance and Biodiversity in Mediterranean-Type Ecosystems; Rundel, P.W., Montenegro, G., Jaksic, F.M., Eds.; Springer: Berlin/Heidelberg, Germany, 1998; pp. 141-154.

42. Nielsen-Pincus, M.; Moseley, C.; Gebert, K. Job growth and loss across sectors and time in the western US: The impact of large wildfires. For. Policy Econ. 2014, 38, 199-206. [CrossRef]

43. Nielsen-Pincus, M.; Moseley, C.; Gebert, K. The effects of large wildfires on employment and wage growth and volatility in the western United States. J. For. 2013, 111, 404-411. [CrossRef]

44. Paliatsos, A.G.; Amanatidis, G.T. Smoke concentrations in Athens, Greece: Trends and strong episodes, 1984-1991. Sci. Total Environ. 1994, 144, 137-144. [CrossRef]

45. Sofiou, F.; Amiridis, V.; Mihalopoulos, N. Smoke plume characteristics over Greece using space-based multiangle imaging. In Proceedings of the First International Conference on Remote Sensing and Geoinformation of the Environment (RSCy2013), Paphos, Cyprus, 10 April 2013; p. 87950D.

46. Richardson, L.A.; Champ, P.A.; Loomis, J.B. The hidden cost of wildfires: Economic valuation of health effects of wildfire smoke exposure in Southern California. J. For. Econ. 2012, 18, 14-35. [CrossRef]

47. Kochi, I.; Donovan, G.H.; Champ, P.A.; Loomis, J.B. The economic cost of adverse health effects from wildfire-smoke exposure: A review. Int. J. Wildland Fire 2010, 19, 803-817. [CrossRef]

48. Thanos, C.Á.; Doussi, M.A. Post-fire regeneration of Pinus brutia forests. In Ecology, Biogeography and Management of Pinus halepensis and P. brutia Forest Ecosystems in the Mediterranean Basin; Backhuys Publishers: Leiden, The Netherlands, 2000; pp. 291-301.

49. Spanos, I.A.; Radoglou, K.M.; Raftoyannis, Y. Site Quality Effects on Post-Fire Regeneration of Pinus brutia Forest on a Greek Island. Appl. Veg. Sci. 2001, 4, 229-236. [CrossRef]

50. Kosmas, C.; Gerontidis, S.; Marathianou, M. The effect of land use change on soils and vegetation over various lithological formations on Lesvos (Greece). CATENA 2000, 40, 51-68. [CrossRef]

51. Palaiologou, P.; Tsiourlis, G.; Kalabokidis, K.; Krallis, F.; Konstantinidis, P. Regeneration of burned Pinus brutia ecosystems in Greece. In Proceedings of the 2nd International Conference on Fire Behaviour and Risk, Sardinia, Italy, $26-29$ May 2015.

52. European Commission, Directorate-General for Climate Action. Special Eurobarometer 459: Climate Change; European Union: Brussels, Belgium, 2017; p. 101.

53. Estrada, M.; Schultz, P.W.; Silva-Send, N.; Boudrias, M.A. The role of social influences on pro-environment behaviors in the San Diego region. J. Urban Health 2017, 94, 170-179. [CrossRef]

54. Lorimer, J. Wildlife in the Anthropocene: Conservation after Nature; University of Minnesota Press: Minneapolis, MN, USA, 2015.

55. Milner-Gulland, E.J.; McGregor, J.A.; Agarwala, M.; Atkinson, G.; Bevan, P.; Clements, T.; Daw, T.; Homewood, K.; Kumpel, N.; Lewis, J.; et al. Accounting for the Impact of Conservation on Human Well-Being. Conserv. Biol. 2014, 28, 1160-1166. [CrossRef]

56. Chan, K.M.A.; Guerry, A.D.; Balvanera, P.; Klain, S.; Satterfield, T.; Basurto, X.; Bostrom, A.; Chuenpagdee, R.; Gould, R.; Halpern, B.S.; et al. Where are Cultural and Social in Ecosystem Services? A Framework for Constructive Engagement. BioScience 2012, 62, 744-756. [CrossRef] 